\title{
Analisis Video Comments to Followers Ratio Instagram pada 5 Band Metal Indonesia yang Go International
}

\author{
IGD Sumardika Waisnawa \\ STIMIK STIKOM Indonesia \\ sumardika832@gmail.com
}

\begin{abstract}
Instagram is one of the most popular social media platforms in the world, especially among young adults. Until the first quarter of 2021, the number of active Instagram users worldwide reached 1.07 billion and 354 million users aged 25 to 34 years. In promoting his musical works in industry 4.0, he utilizes social media platforms that are easily accessible by many people, namely the use of online media in promotions such as YouTube, Facebook, Whatsapp, Instagram, marketing content, content creation for promotional materials that will be uploaded on social media., mobile marketing is the selection of social media that is easily accessible via smartphones with many users so that the target market is in accordance with what has been planned so that the marketing goals are achieved. The 5 Metal Bands that use Instagram are: Deadsquad, Burgerkill, Jasad, Beside, Down For Life. The purpose of this study is to calculate the credibility of the Instagram account performance on 5 Indonesian Metal Bands that Go International. The method used for this research is quantitative exploratory method. The results of this study indicate that Deadsquad is ranked first and has good account performance credibility.
\end{abstract}

\footnotetext{
ABSTRAK

Instagram merupakan adalah salah satu platform media sosial yang paling populer di dunia, terutama di kalangan dewasa muda. Hingga kuartal I-2021, jumlah pengguna aktif Instagram di seluruh dunia mencapai 1,07 miliar dan 354 juta penggunanya berusia 25 hingga 34 tahun. Dalam melakukan promosi hasil karya musiknya di industri 4.0 ini memanfaatkan platform media sosial yang mudah diakses oleh banyak orang yaitu penggunaan media online dalam melakukan promosi seperti YouTube, Facebook, Whatsapp, Instagram konten marketing pembuatan konten untuk bahan promosi yang akan diunggah di media-media sosial, mobile marketing pemilihan media sosial yang mudah diakses dengan mudah melalui smartphone yang banyak penggunanya supaya target marketnya sesuai dengan yang sudah direncanakan sehingga tujuan pemasarannya tercapai. Adapun 5 Band Metal yang menggunakan Instagram
} 
yaitu: Deadsquad, Burgerkill, Jasad, Beside, Down For Life. Tujuan dari penelitian ini yaitu untuk menghitung kredibilitas dari performa akun Instagram pada 5 Band Metal Indonesia yang Go International. Metode yang digunakan untuk penelitian ini yaitu metode eksploratif kuantitatif. Hasil dari penelitian ini menunjukan bahwa Deadsquad mendapatkan peringkat pertama dan memiliki kredibilitas performa akun yang baik.

\section{PENDAHULUAN}

Teknologi informasi dan komunikasi yang telah berkembang pesat mampu menghantarkan manusia untuk menciptakan bentuk baru cara berkomunikasi dan berinteraksi melalui media sosial. Sarana berkomunikasi menggunakan media sosial sangat berperan dalam aktifitas keseharian bersosial di masyarakat.

Teknologi informasi dan komunikasi dirasa penting keberadaannya oleh penggunanya, dimana salah satu tujuannya adalah untuk bertukar infomasi. Keberadaan sarana komunikasi ini memberikan dampak yang signifikan di berbagai bidang seperti, sosial, ekonomi, Pendidikan dan bidang lainnya. Komunikasi tidak hanya dapat di lakukan secara fisik, tetapi juga dapat di lakukan dengan menggunakan berbagai media sosial di dunia maya. Keunggulan layanan media sosial adalah memberikan ruang komunikasi dua arah antara konsumen perusahaan dan konsumen-konsumen. Komunikasi dua arah ini memampukan konsumen untuk berpartispasi, kolaborasi dan berinteraksi, yang pada intinya konsumen tidak lagi objek tetapi subyek pemasaran.

Dengan pesatnya perkembangan teknologi media sosial, telah memberikan dampak terhadap situs - situs komunikasi, dari yang awalnya hanya sekedar email, dan chatting, sekarang sudah banyak jejaringan media sosial yang bisa digunakan sebagai alat komunikasi. Contohnya seperti, facebook, Instagram, twitter, Telegram, Snapchat.

Instagram adalah salah satu platform media sosial yang paling populer di dunia, terutama di kalangan dewasa muda. Hingga kuartal I-2021, jumlah pengguna aktif Instagram di seluruh dunia mencapai 1,07 miliar dan 354 juta penggunanya berusia 25 hingga 34 tahun. (Mafulla, Dian; Kholik, Abdul n.d.). Instagram adalah media sosial yang digunakan sebagai tempat menyebarkan dan berbagai informasi, berinteraksi dengan orang banyak, serta dapat mengenal lebih dekat dengan sesama pengguna . Instagram merupakan aplikasi berbagi foto 
yang memungkinkan pengguna mengambil foto, menerapkan filter digital, dan membagikannya ke berbagai layanan jejaring sosial (Hendika Permana, I Putu 2021).

Media sosial Instagram telah menimbulkan isu-isu penting yang terkait dengan kebebasan berekspresi. Tidak ada pusat dan tombol untuk mematikan dan menyalakan Internet sehingga Internet menjadi sulit dikendalikan oleh orang yang ingin melakukannya. Namun, bagi para pembela kebebasan berekspresi, kebebasan dari adanya kontrol inilah yang menjadi kekuatan utama medium ini (Mahendra, Bimo 2017). Dalam melakukan promosi hasil karya musiknya di industri 4.0 ini memanfaatkan platform media sosial yang mudah diakses oleh banyak orang yaitu penggunaan media online dalam melakukan promosi seperti YouTube, Facebook, Whatsapp, Instagram konten marketing pembuatan konten untuk bahan promosi yang akan diunggah di media-media sosial mobile marketing pemilihan media sosial yang mudah diakses dengan mudah melalui smartphone yang banyak penggunanya supaya target marketnya sesuai dengan yang sudah direncanakan sehingga tujuan pemasarannya tercapai. (Muhammad, Yus Rizal;Rachman, Abdul 2020).

Penelitian ini menggunakan metode eksploratif kuantitatif, dan akan menghitung menggunakan rasio-rasio yang ada pada Instagram. Terdapat 14 rasio yang ada pada sosial media Instagram dan relevan digunakan sebagai media ukur kredibilitas akun yang ada.Penelitian ini hanya berfokus untuk menghitung kredibilitas Video Comments to Followers Ratio Instagram pada 5 Band Metal Indonesia yang Go International. Tujuan dari penelitian ini adalah mengetahui kredibilitas performa dari akun Instagram 5 Band Metal Indonesia yang Go International.

\section{TINJAUAN PUSTAKA}

Perkembangan bidang teknologi saat ini terjadi begitu pesat. Melalui perkembangan yang terjadi dari waktu ke waktu menimbulkan maraknya aplikasi - aplikasi serta platform media sosial yang bermunculan. Aplikasi yang sangat diminati oleh masyarakat saat ini diantaranya adalah TikTok, Instagram, Twitter, WhatsApp dan yang lain sebagainya. Seiring berjalannya waktu, aplikasi sosial media tersebut dapat menjadi candu bagi kalangan masyarakat. Tidak hanya kalangan remaja yang menggunakan aplikasi sosial media, orang tua bahkan anak-anak juga aktif menggunakan aplikasi sosial media tersebut. 
Penggunaan media sosial, sebuah perusahaan riset dan analisis dari Inggris, TNS, menyebutkan bahwa Indonesia berada diperingkat ke-3 pengguna Instagram. (Sari, Puspita 2017). Selain facebook, twiter, whatsapp dan youtube yang menjadi media sosial favorit adalah instagram. Di Indonesia, jumlah pengguna Instagram hingga Juli 2021 sebesar 91,77 juta pengguna. Pengguna terbesar terdapat di kelompok usia 18 - 24 tahun yaitu 36,4\%. Instagram berada di urutan ketiga sebagai platform media sosial yang paling sering digunakan, setelah YouTube dan WhatsApp. Instagram menjadi media sosial yang sangat populer di berbagai belahan dunia karena memungkinkan penggunanya untuk berbagi konten fotografi serta mengikuti kehidupan para pesohor favorit (Mafulla, Dian; Kholik, Abdul n.d.).

Instagram merupakan salah satu media sosial dimana kita bisa memilih orang yang kita ajak gabung sebagai teman kita. Kita pun bisa menolak pertemanan jika memang kita tidak menginginkannya. Inilah yang dinamakan bahwa suatu komunitas berdiri atau terbentuk dengan sendirinya sesuai dengan yang kita inginkan. (Prihatiningsih, Witanti 2017).

Instagram pertama kali hadir di Appstore (aplikasi yang menyediakan program untuk digunakan smartphone keluaran Apple) pada tanggal 6 Oktober 2010. Sebuah perusahaan berbasis teknologi Burbn.Inc membuat aplikasi yang memungkinkan pengunakanya mengambil foto, menerapkan filterdigital dan membagikannya melalui akun Instagram penggunanya dan jejaring sosial media lain. Meski fiturnya tidak selengkap platform sosial media lain, Instagram cukup diminati dan menjadi tempat yang strategis bagi para pebisnis pemula untuk memasarkan produknya. Bahkan saat ini industri yang sudah mapan pun mulai melirik Instagram sebagai media yang efektif untuk mendekatkan dan memasarkan produknya pada pengguna Instagram yang kebanyakan adalah generasi muda (Fenomenologi, Studi 2017).

Instagram dirasakan memiliki kekuatan ataupun pengaruh dalam industri, sehingga menimbulkan kualitas akun yang menentukan strata maupun kredibilitas pemilik akun. Kredibilitas akun Instagram merupakan suatu hal yang cukup penting untuk berbagai kepentingan. Kredibilitas sebuah akun Instagram dapat diukur dari tingkat performa yang dihasilkan secara matematis. Dalam mengukur performa diperlukan skala pengukuran yang tertuang ke dalam rasio.

\section{METODE PENELITIAN}


Penelitian ini menggunakan metode eksploratif kuantitatif untuk mengetahui kredibilitas dari performa akun Instagram dari ke 5 Band Metal Indonesia yang Go Internasional. Penelitian tipe eksploratif, bertujuan memperdalam pengetahuan dan mencari ide-ide baru mengenai suatu gejala tertentu, menggambarkan fenomena sosial, dan menjelaskan bagaimana terjadinya suatu fenomena sosial untuk merumuskan masalah secara lebih terperinci atau mengembangkan hipotesis bukan menguji hipotesis. (Mudjiyanto, Bambang 2018).

Tujuan dari penelitian ini yaitu untuk mengetahui nilai kredibillitas dari performa akun Instagram dari ke 5 Band Metal Indonesia yang Go Internasional. Ada beberapa langkahlangkah yang harus dilakukan dalam penelitian ini, sehingga mampu menemukan peringkat pertama akun Instagram dari ke 5 Band Metal Indonesia yang Go Internasional ini, yang memiliki performa paling baik. Langkah-langkah yang dilakukan pada penelitian ini, diantaranya yaitu :

\section{Melakukan Eksplorasi Pada Website Untuk Menentukan Objek yang Akan Dianalisa.}

Eksplorasi ini dilakukan pada beberapa halaman website yang menyediakan informasi mengenai objek yang akan di teliti. Setelah eksplorasi selesai dilakukan, sehingga ditemukan nama-nama Band Metal Indonesia yang Go Internasional, yang akan dijadikan objek analisa. Setelah melakukan eksplorasi pada halaman website, maka langkah selanjutnya yaitu mencari nama akun Instagram dari masing-masing Band Metal tersebut. Pastikan semua Band Metal memiliki akun pada aplikasi sosial media Instagram.

\section{Menghitung Nilai Rata-Rata Variable Dari ke 5 Band Metal Indonesia yang Go Internasional.}

Pada langkah ini, peneliti menghitung nilai variable Video Comments to Followers Ratio. Variabel adalah sesuatu yang memiliki nilai bervariasi dimana nilai tersebut dapat dijadikan dasar untuk 4 data yang berbeda seperti rasio, skala, ordinal, nominal dan internal (Hendika Permana, I Putu 2021). Untuk menghitung nilai rata-rata dari variabel Video Comments to Followers Ratio yaitu dengan cara mengambil minimal 10 postingan kemudian di hitung sehingga menemukan nilai rata-rata dari masing-masing variabel. 


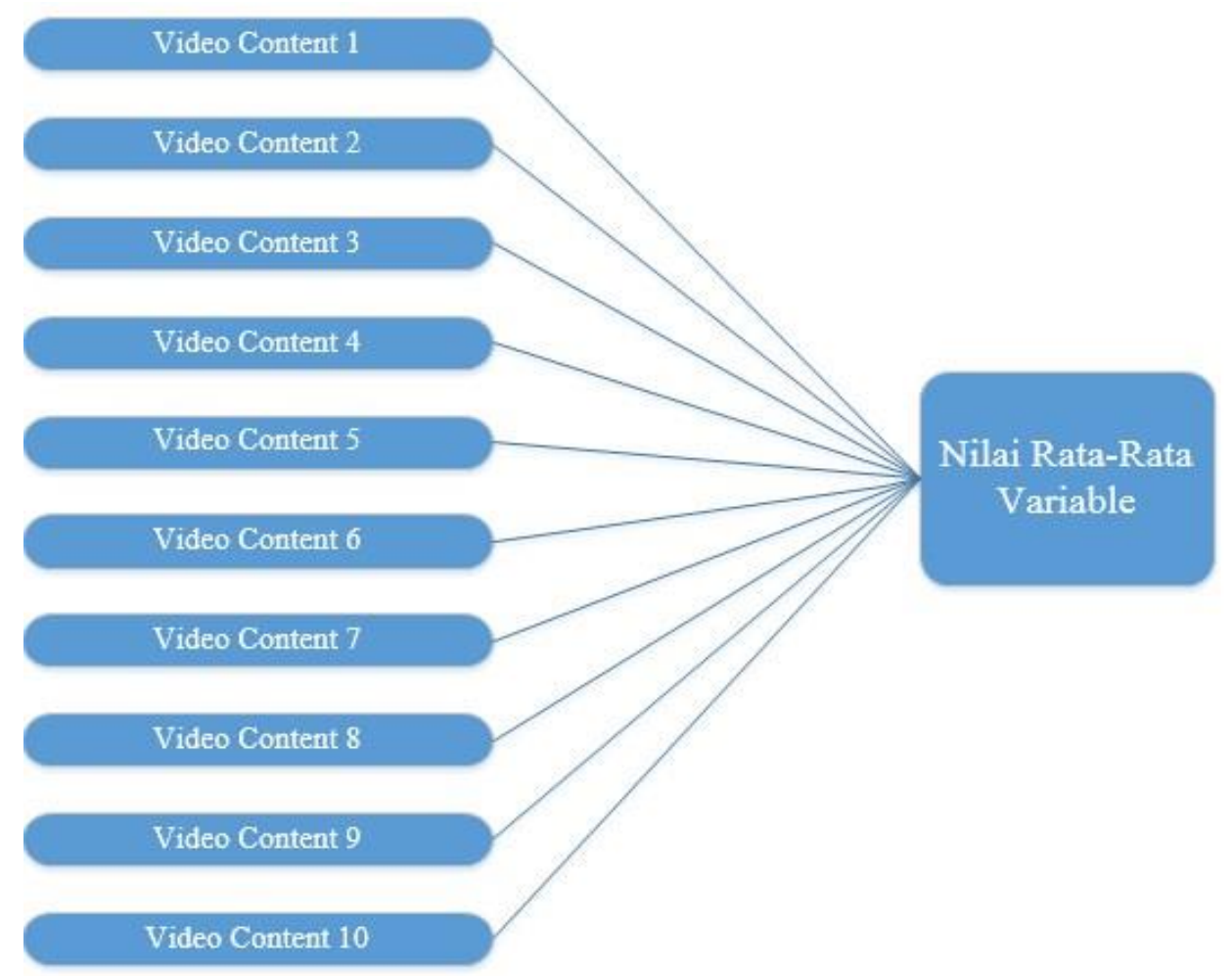

\section{Menghitung Nilai Kredibilitas Rasio}

Untuk menghitung nilai kredibilitas dari Video Comments to Followers Ratio, peneliti menggunakan cara membagi nilai variabel pertama dengan nilai variabel kedua. Jika video comments memiliki nilai 100 dan followers ratio memiliki nilai 300, maka cara menghitungnya yaitu $100: 300=0,3$. Dengan begitu nilai dari Video Comments to Followers Ratio adalah 0,3.

\section{Menentukan Peringkat Pada Akun Instagram}

Langkah paling terakhir yang dilakukan oleh peneliti pada penelitian ini yaitu menentukan peringkat pada masing-masing rasio yang ada. Pada penentuan peringkat perlu melihat karakteristik dari rasio yang di teliti. Jika karakteristik rasio merupakan rendah, maka objek yang memiliki nilai terendah akan mendapatkan angka 5 dan objek yang memiliki nilai tertinggi akan mendapatkan angka 1. Namun jika rasio memiliki karakteritik tinggi maka objek yang mendapatkan nilai tinggi akan mendapatkan angka 5 dan objek yang mendapatkan nilai terendah akan mendapatkan angka 1. Setelah mendapatkan hasil kredibilitas ratio maka dapat disimpulkan objek yang mana mendapatkan peringkat 1 sampai dengan peringkat 5 .

\section{HASIL DAN PEMBAHASAN}

Akun Instagram dari ke 5 Band Metal Indonesia yang Go Internasional, diantaranya : 


\section{Deadsquad}
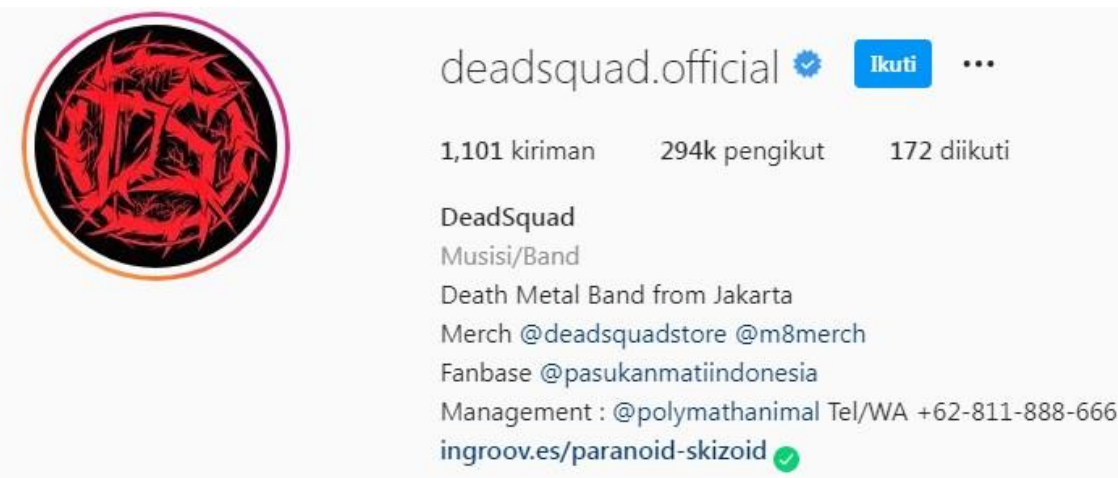

Gambar 1. Akun Instagram Deadsquad

Sumber : https://www.instagram.com/deadsquad.official/ (akses pada 22-10-2021)

\section{Burgerkill}

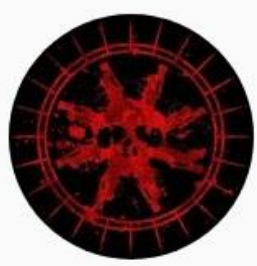

\section{burgerkillofficial Ikuti $\cdots$}

1,779 kiriman $\quad 453 k$ pengikut 217 diikuti

BURGERKILL

Band

The official Instagram page for Indonesian hardcore metal band Burgerkill.

Click the link for more music, videos, and merch! www.burgerkillonline.com

Gambar 2. Akun Instagram Burgerkill

Sumber : https://www.instagram.com/burgerkillofficial/ (akses pada 22-10-2021)

\section{Jasad}
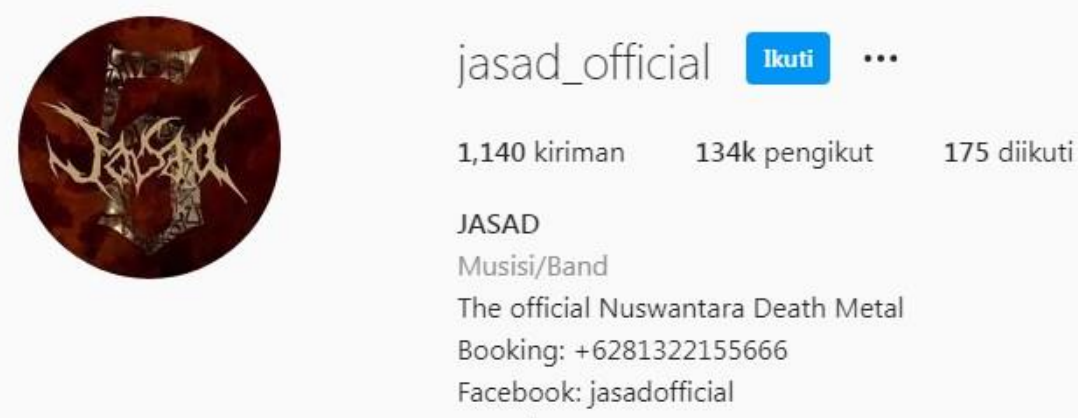

Gambar 3. Akun Instagram Jasad

Sumber : https://www.instagram.com/jasad_official//akses pada 22-10-2021)

\section{Beside}



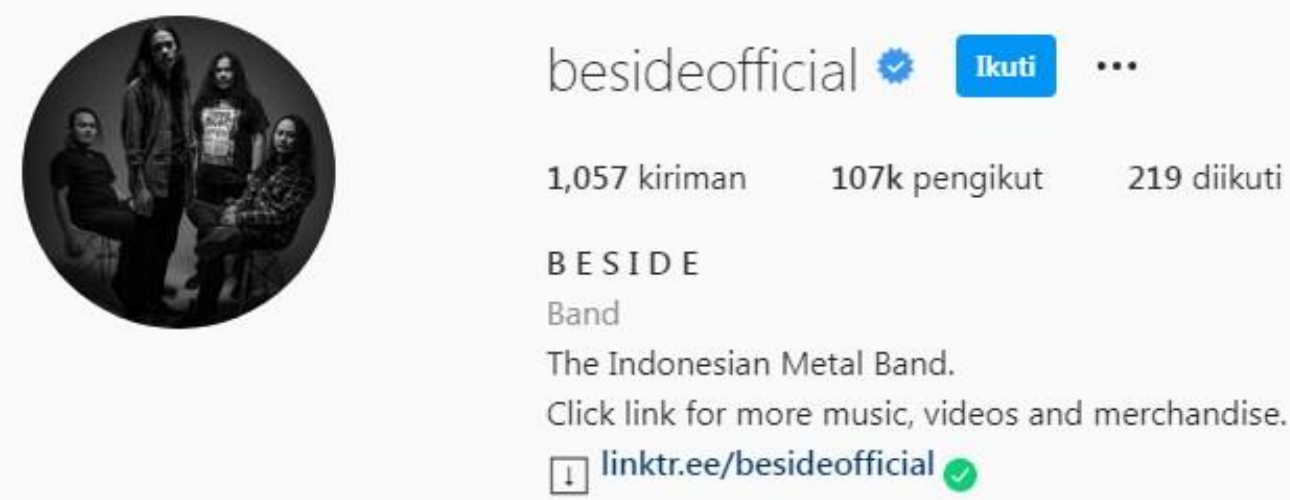

Gambar 4. Akun Instagram Beside

Sumber : https://www.instagram.com/besideofficial/ (akses pada 22-10-2021)

\section{Down for life}

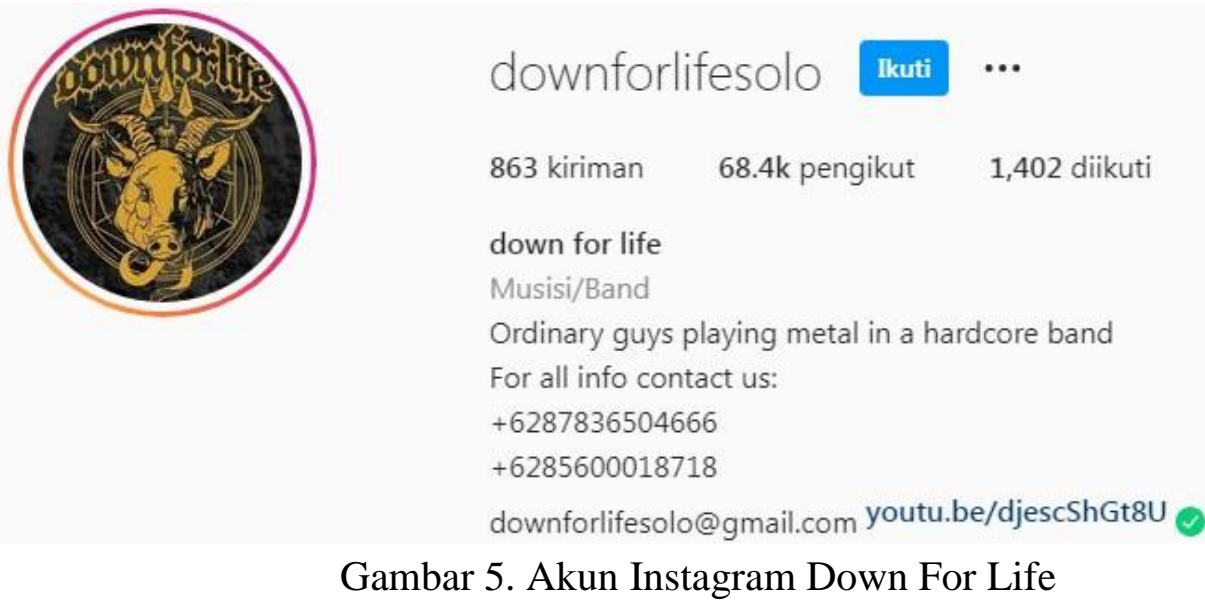

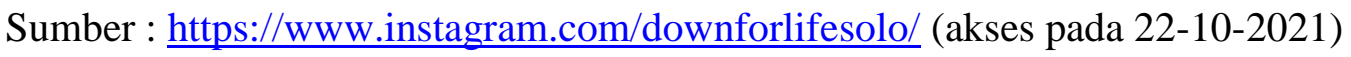

Dari kelima akun Instagram Band Metal Indonesia yang Go Internasional, peneliti menemukan nilai dari masing-masing variabel yang ada untuk menghitung Video Comment to Followers Ratio dari setiap akun. Pada akun Instagram terdapat 8 variabel, diantaranya yaitu :

1. Posts

2. Followers

3. Following

4. Image Likes

5. Image Comments

6. Video Views

7. Video Likes

8. Video Comments 
Dari kedelapan variabel tersebut peneliti hanya fokus untuk menemukan hasil dari 2 variabel, yaitu :

1. Video comments

2. Followers ratio

Dari kedua variabel tersebut kemudian dianalisa sehingga menemukan nilai rata-rata dari variabel Video Comment to Followers Ratio. Untuk menghitung nilai rata-rata dari variabel video comments to followers ratio yaitu dengan cara mengambil minimal 10 postingan kemudian di hitung sehingga menemukan nilai rata-rata dari masing-masing variabel. Berikut merupakan tabel nilai rata-rata dari masing-masing Band Metal yang Go Internasional, yaitu

Tabel 1. Analisa Nilai Rata-Rata Nilai Variabel Video Comment to Followers Ratio Akun Deadsquad

\begin{tabular}{|c|c|c|}
\hline No & Video Comments & Followers ratio \\
\hline 1 & 248 & 294.000 \\
\hline 2 & 205 & 294.000 \\
\hline 3 & 751 & 294.000 \\
\hline 4 & 3.997 & 294.000 \\
\hline 5 & 2.021 & 294.000 \\
\hline 6 & 283 & 294.000 \\
\hline 7 & 287 & 294.000 \\
\hline 8 & 377 & 294.000 \\
\hline 9 & 60 & 294.000 \\
\hline 10 & 110 & 294.000 \\
\hline rata-rata & $\mathbf{8 3 4}$ & $\mathbf{2 9 4 . 0 0 0}$ \\
\hline \multicolumn{3}{|c|}{ Sumber $:$ pengolah Data Excel } \\
\hline
\end{tabular}

Tabel 2. Analisa Nilai Rata-Rata Nilai Variabel Video Comment to Followers Ratio Akun Burgerkill

\begin{tabular}{|c|r|r|}
\hline No & Video Comments & Followers ratio \\
\hline 1 & 848 & 453.000 \\
\hline 2 & 134 & 453.000 \\
\hline 3 & 61 & 453.000 \\
\hline 4 & 4 & 453.000 \\
\hline 5 & 148 & 453.000 \\
\hline 6 & 403 & 453.000 \\
\hline 7 & 168 & 453.000 \\
\hline 8 & 118 & 453.000 \\
\hline 9 & 50 & 453.000 \\
\hline 10 & 265 & 453.000 \\
\hline
\end{tabular}




\begin{tabular}{|r|r|r|} 
rata-rata & 220 & $\mathbf{4 5 3 . 0 0 0}$ \\
\hline
\end{tabular}

Tabel 3. Analisa Nilai Rata-Rata Nilai Variabel Video Comment to Followers Ratio Akun Jasad

\begin{tabular}{|c|r|r|}
\hline No & Video Comments & Followers ratio \\
\hline 1 & 25 & 134.000 \\
\hline 2 & 1 & 134.000 \\
\hline 3 & 20 & 134.000 \\
\hline 4 & 5 & 134.000 \\
\hline 5 & 10 & 134.000 \\
\hline 6 & 5 & 134.000 \\
\hline 7 & 4 & 134.000 \\
\hline 8 & 17 & 134.000 \\
\hline 9 & 39 & 134.000 \\
\hline 10 & 18 & 134.000 \\
\hline rata-rata & 14 & $\mathbf{1 3 4 . 0 0 0}$ \\
\hline
\end{tabular}

Tabel 4. Analisa Nilai Rata-Rata Nilai Variabel Video Comment to Followers Ratio

Akun Beside

\begin{tabular}{|c|r|r|}
\hline No & Video Comments & Followers ratio \\
\hline 1 & 44 & 107.000 \\
\hline 2 & 74 & 107.000 \\
\hline 3 & 21 & 107.000 \\
\hline 4 & 1 & 107.000 \\
\hline 5 & 10 & 107.000 \\
\hline 6 & 238 & 107.000 \\
\hline 7 & 48 & 107.000 \\
\hline 8 & 19 & 107.000 \\
\hline 9 & 31 & 107.000 \\
\hline 10 & 40 & 107.000 \\
\hline rata-rata & $\mathbf{5 3}$ & $\mathbf{1 0 7 . 0 0 0}$ \\
\hline
\end{tabular}

Sumber : pengolah Data Excel

Tabel 5. Analisa Nilai Rata-Rata Nilai Variabel Video Comment to Followers Ratio Akun Down For Life

\begin{tabular}{|c|r|r|}
\hline No & Video Comments & Followers ratio \\
\hline 1 & 93 & 67.700 \\
\hline 2 & 78 & 67.700 \\
\hline 3 & 80 & 67.700 \\
\hline 4 & 22 & 67.700 \\
\hline 5 & 127 & 67.700 \\
\hline 6 & 16 & 67.700 \\
\hline 7 & 23 & 67.700 \\
\hline
\end{tabular}




\begin{tabular}{|c|r|r|}
8 & 12 & 67.700 \\
\hline 9 & 257 & 67.700 \\
\hline 10 & 56 & 67.700 \\
\hline rata-rata & $\mathbf{7 6}$ & $\mathbf{6 7 . 7 0 0}$ \\
\hline
\end{tabular}

Sumber : pengolah Data Excel

Setelah menghitung nilai rata-rata tersebut, maka akan menemukan hasil akhir nilai rata rata dari variabel Video Comment to Followers Ratio.

Tabel 6. Nilai Variabel Pada Akun Instagram dari ke 5 Band Metal Indonesia yang Go Internasional

\begin{tabular}{|c|c|c|c|c|c|}
\hline Variable & Deadsquad & Burgerkill & Jasad & Beside & $\begin{array}{c}\text { Down For } \\
\text { Life }\end{array}$ \\
\hline $\begin{array}{c}\text { Video } \\
\text { comments }\end{array}$ & 834 & 220 & 14 & 53 & 76 \\
\hline $\begin{array}{c}\text { Followers } \\
\text { ratio }\end{array}$ & 294000 & 453000 & 134000 & 107000 & 67700 \\
\hline
\end{tabular}

Sumber : pengolah Data Excel

Pada akun Instagram terdapat 14 rasio yang relevan digunakan untuk mengukur kredibilitas pada masing-masing akun. Namun pada penelitian kali ini hanya berfokus untuk menghitung Video Comment to Followers Ratio. Untuk menghitung kredibilitas dari masing-masing akun Instagram setiap Band Metal yang Go Internasional, peneliti menghitung dengan cara : variabel 1 akan dibagi dengan variabel 2, sehingga ditemukan hasil analisisa dari rasio tersebut.

Tabel 7. Hasil Perhitungan Rasio Akun Instagram

\begin{tabular}{|c|c|c|c|c|c|c|}
\hline No & RATIO & & & & & \\
& & Deadsquad & Burgerkill & Jasad & Beside & $\begin{array}{c}\text { Down For } \\
\text { Life }\end{array}$ \\
\hline & $\begin{array}{c}\text { Video } \\
\text { Comments to } \\
\text { Followers Ratio }\end{array}$ & 0,00283673 & 0,00048565 & 0,00010448 & 0,00049533 & 0,00112260 \\
\hline
\end{tabular}

Sumber : pengolah Data Excel

Video Comment to Followers Ratio memiliki karakteristik yang tinggi, artinya semakin tinggi nilai yang dihasilkan maka semakin baik kredibilitas dari performa akun tersebut. Untuk memberikan peringkat pada masing-masing Band Metal tersebut, peneliti memberikan angka 5 kepada Band Metal yang mendapatkan nilai tertinggi dan angka 1 untuk Band Metal 
yang mendapatkan nilai terendah. Berikut merupakan tabel urutan nilai yang dihasilkan oleh masing-masing Band Metal tersebut.

Tabel 8. Nilai Rasio Akun Instagram dari ke 5 Band Metal Indonesia yang Go

\begin{tabular}{|c|c|c|c|l|}
\hline & & & Internasional & $\begin{array}{l}\text { Down For } \\
\text { Life }\end{array}$ \\
\hline 5 & Burgerkill & Jasad & Beside & 4 \\
\hline
\end{tabular}

Sumber : pengolah Data Excel

Dari Tabel Nilai Rasio Akun Instagram dari ke 5 Band Metal Indonesia yang Go Internasional dapat simpulkan bahwa Deadsquad mendapatkan nilai tertinggi untuk rasio Video Comment to Followers Ratio. Sedangkan akun Instagram Jasad mendapatkan nilai terendah untuk rasio ini. Jadi, pada penelitian ini Deadsquad memiliki kredibilitas performa yang lebih baik dibandingkan dengan Band Metal yang lainnya.

\section{KESIMPULAN}

Tujuan dari penelitian ini adalah mengetahui kredibilitas performa dari Akun Instagram dari ke 5 Band Metal Indonesia yang Go Internasional menggunakan Video Comment to Followers Ratio. 5 Band Metal Indonesia yang Go Internasional diantaranya adalah Deadsquad, Burgerkill, Jasad, Beside, Down For Life. Dari kelima Band Metal tersebut dapat disimpulkan bahwa :

1. Peringkat pertama diraih oleh Deadsquad dengan nilai tertinggi yaitu 0,00283673

2. Peringkat kedua diraih oleh Down For Life dengan nilai 0,00112260

3. Peringkat ketiga diraih oleh Beside dengan nilai 0,00049533

4. Peringkat keempat diraih oleh Burgerkill dengan nilai 0,00048565

5. Peringkat kelima diraih oleh Jasad dengan nilai terendah yaitu 0,00010448 


\section{DAFTAR PUSTAKA}

Fenomenologi, Studi. 2017.

Hendika Permana, I Putu. Jurnal Ilmiah Media Sisfo, 2021: 40.

Hendika Permana, I Putu. Jurnal Ilmiah Media Sisfo, 2021: 40.

Mafulla, Dian, Kholik, Abdul. Efektifitas Media Sosial Instagram Sebagai Strategi Promosi

Online Kawasan Wisata Pacet Mojokerto, t.thn.: 1-8.

Mafulla, Dian; Kholik, Abdul. n.d.: 1-8.

Mahendra, Bimo. Jurnal Visi Komunikasi, 2017: 151-160.

Mudjiyanto, Bambang. Jurnal Studi Komunikasi dan Media, 2018: 65.

Muhammad, Yus Rizal. Musikolastika: Jurnal Pertunjukan dan Pendidikan Musik, 2020: 2330 .

Muhammad, Yus Rizal;Rachman, Abdul. Musikolastika: Jurnal Pertunjukan dan Pendidikan Musik, 2020.

Muhammad, Yus Rizal;Rachman, Abdul. Musikolastika: Jurnal Pertunjukan dan Pendidikan Musik, 2020: 23-30.

Prihatiningsih, Witanti. Communication, 2017: 51.

Sari, Puspita. Fenomena Penggunan Media Sosial Instagram Sebagai Komunikasi

Pembelajaran Agama Islam Oleh Mahasiswa Fisip Universitas Riau, 2017: 1-13. 